\title{
Response of Big Game Winter Range Vegetation to Fertilization
}

\section{MOHAMED A. BAYOUMI AND ARTHUR D. SMITH}

Highlight: Nitrogen and phosphorus, alone and in combination, were applied to bitterbrush (Purshia tridentata) and sagebrush (Artemisia tridentata) and three herbaceous species, beardless wheatgrass (Agropyron inerme), prairie Junegrass (Koeleria cristata), and Pacific aster (Aster chilensis). Spring applications of nitrogen significantly increased forage production of the three herbaceous species; twig growth, seed production, and percent crude protein of the leaves and twigs of bitterbrush and sagebrush were increased also. Throughout the winters of 1972-73 and 1973-74, the nitrogen-fertilized bitterbrush and sagebrush plants were used more heavily by elk than the unfertilized plots. Neither yields nor utilization were increased by phosphorus.

Literature on the effects of nitrogen fertilizer on native rangelands suggests that there are possibilities for increasing production and improving the quality of forage on game ranges (Wood and Lindzey, 1967; Carpenter, 1971; Anderson, 1972; Williams, 1972). Tests have shown the value of nitrogen fertilizers on seeded foothill ranges in Utah (Cook and Stoddart, 1959; Cook, 1961), but no data were available on response of native stands on big game range in the Intermountain area. Carpenter (1971) found a linear increase in both browse and herbaceous species production to each increased increment of nitrogen fertilizers from 30 to 120 pounds of nitrogen per acre on game ranges in Colorado. Williams (1972) applied nitrogen to sagebrush and reported greatly increased percentages of protein in forage available to deer during the winter.

\footnotetext{
Authors were graduate student and professor emeritus, Range Science Department, Utah State University, respectively. The research reported herein was conducted by the senior author to satisfy requirements for a doctoral degree in range science. He is now on the Faculty of Agriculture, Tripoli University, Libya.

Acknowledgement is made for the co. operation of the Utah State Division of Wildlife Resources who made the area at the Hardware Ranch available for the study and who supplied the fertilizer used.
}

Manuscript received February 17, 1975.
A number of researchers have reported that plants stimulated by adding nitrogen are more palatable to grazing animals than unfertilized plants and are used more by both domestic and wild animals. Smith (1963) determined that winter use of big sagebrush twigs by deer was greater on plots treated with 400 pounds of ammonium phosphate per acre (448 $\mathrm{kg} / \mathrm{ha}$ ) than on unfertilized plots. Preference by deer for nitrogen-fertilized browse plants has also been found by Anderson (1972) in New Mexico. According to Geist et al. (1974), elk were attracted to meadow plots where nitrogenous fertilizers had been applied.

The study reported here examined the effects of nitrogen and phosphorus fertilizers, used separately and in combination, on the yield of bitterbrush (Purshia tridentata) and sagebrush (Artemisia tridentata) and three associated herbaceous plants-Pacific aster (Aster chilensis), beardless wheatgrass (Agropyron inerme), and prairie Junegrass (Koeleria cristata); the effects of nitrogen fertilizer on crude protein content of the current year's growth of bitterbrush and sagebrush; and compared use of fertilized and unfertilized bitterbrush and sagebrush plants by elk and deer.

\section{Study Area and Methods}

The study was conducted on biggame winter range at the Hardware Ranch in Blacksmith Fork Canyon, Cache County, Utah. Both elk (Cervus canadensis) and mule deer (Odocoileus hemionus) winter on this and adjacent areas almost 7 months, from October through April. However, no livestock grazing has been allowed since the area was purchased by the Utah State Division of Wildlife Resources in 1946 (Smith and Doell, 1968). The elevation of the area varies from approximately 1,600 to 1,900 meters. The soils belong to the Ant Flat and Yeates Hollow series, which were derived from quartzite and quartzitecalcareous sandstone parent material, respectively. Average annual precipitation is about $406 \mathrm{~mm}$. Summer precipitation, June to September, was $62.7 \mathrm{~mm}$ in 1972 and $162.6 \mathrm{~mm}$ in 1973. The vegetation on the study area is a sagebrush-grass type representative of mountain foothill big game winter ranges of northern Utah.

In an effort to stimulate the two browse species most important as winter forage for big game, bitterbrush and sagebrush, nitrogen and phosphorus fertilizers alone and in combination were applied to plots in the spring of 1972. Only nitrogen was applied in 1973. Fertilizers were applied only once. Ammonium nitrate was the source of nitrogen, except one level of fertilization was duplicated using calcium nitrate in order to test the stability of nitrogen in commercial forms. Phosphorus was applied as treble superphosphate. Fertilizers were spread by hand-broadcasting except for one level of phosphorus which was placed below ground in holes to insure contact with roots of the shrubs. Plots were $100.8 \mathrm{ft}^{2}$, circular, and were centered over a shrub.

The experiment was designed as a randomized block with ten replications of eight fertilizer treatments in 
Table 1. Percent increase of air-dry production of beardless wheatgrass, prairie Junegrass, and Pacific aster and of twig growth of bitterbrush and sagebrush on the 1972-treated plots in 1972 and 1973 and on the 1973-treated plots in 1973.

\begin{tabular}{|c|c|c|c|c|c|c|c|c|c|c|}
\hline \multirow[b]{3}{*}{ Species } & \multicolumn{6}{|c|}{ Fertilization rates, $1972(\mathrm{~kg} \mathrm{~N} / \mathrm{ha})^{2}$} & & & & \\
\hline & \multicolumn{2}{|c|}{33.6} & \multicolumn{2}{|c|}{67.2} & \multicolumn{2}{|c|}{100.8} & \multicolumn{4}{|c|}{ Fertilization rates, $1973(\mathrm{~kg} \mathrm{~N} / \mathrm{haa})^{2}$} \\
\hline & $\widehat{1972}$ & $\overline{1973}$ & 1972 & $\overline{1973}$ & 1972 & 1973 & 67.2 & 100.8 & 134.4 & 168.0 \\
\hline Beardless wheatgrass & 22 & 65 & 46 & 75 & 85 & 101 & 109 & 126 & 137 & 165 \\
\hline Prairie J unegrass & 11 & 61 & 52 & 93 & 99 & 143 & 124 & 152 & 165 & 186 \\
\hline Pacific aster & 30 & 28 & 58 & 61 & 79 & 114 & 99 & 127 & 150 & 172 \\
\hline Mean & 21.0 & 51.3 & 52.0 & 76.3 & 87.7 & 119.3 & 110.7 & 135.0 & 150.7 & 174.3 \\
\hline Bitterbrush & 35 & 30 & 58 & 45 & 91 & 69 & 40 & 57 & 69 & 76 \\
\hline Sagebrush & 36 & 24 & 74 & 49 & 103 & 97 & 37 & 66 & 89 & 117 \\
\hline Mean & 35.5 & 27.0 & 66.0 & 47.0 & 97.0 & 83.0 & 38.5 & 61.5 & 79.0 & 96.5 \\
\hline
\end{tabular}

${ }^{1}$ All differences are significant at the $1 \%$ level except for Pacific aster in 1973 which was significant at $5 \%$

2 Fertilizers were applied in early spring each year.

1972 and five fertilizer treatments in 1973 with unfertilized control plots. Ammonium nitrate application rates were $0,33.6,67.2,100.8 \mathrm{Kg} \mathrm{N} / \mathrm{ha}$ in 1972 and $0,67.2,100.8,134.4$, and $168 \mathrm{~kg} \mathrm{~N} / \mathrm{ha}$ in 1973. Application rates of phosphorus were $0,33.6,67.2$ (combined with $100.8 \mathrm{~kg} \mathrm{~N} / \mathrm{ha}$ ), and $100.8 \mathrm{~kg} \mathrm{P} / \mathrm{ha}$ in 1972 . Hereafter, the levels of nitrogen will be referred to as $\mathrm{N}_{1}(33.6 \mathrm{~kg} / \mathrm{ha}), \mathrm{N}_{2}(67.2 \mathrm{~kg} / \mathrm{ha}), \mathrm{N}_{3}$ $(100.8 \mathrm{~kg} / \mathrm{ha}), \mathrm{N}_{4}(134.4 \mathrm{~kg} / \mathrm{ha})$, and $\mathrm{N}_{5}(168 \mathrm{~kg} / \mathrm{ha})$.

The weight-estimate method, as described by Pechanec and Pickford (1937) was used for determining the forage production of the three herbaceous species. Productivity of shrubs was determined by measuring the length of the current year's twig growth. Twenty twigs were randomly selected and measured on each bush using the method described by Smith and Doell (1968). There were 10 plots per treatment. Measurements were made at the end of growing season in September.

Seed for bitterbrush and seed stalks of sagebrush were determined by counting the number of each occurring in 36 randomized grid squares, 5.08 $\mathrm{cm}$ on a side, a total area of 0.093 square meters, on a circular hoop 71.4 $\mathrm{cm}$ in diameter suspended over each of the 10 bushes in each treatment (Smith and Doell, 1968).

The effect of fertilization upon utilization of bitterbrush and sagebrush by elk and deer was determined using the conventional before- and after-use twig length measurements (Smith and Urness, 1962). Measurements were made on one tagged branch on each shrub at the end of the growing season and again periodically after the elk had moved into the area so that the time of utilization could be ascertained.

Percent crude protein contents of browse samples, leaves in 1972 and both leaves and twigs in 1973, were determined by the Kjeldahl apparatus following procedures outlined by Harris (1970).

\section{Results}

No response was observed from applying phosphorus to either the browse or herbaceous species. Inserting phosphorus in holes to a depth of $10 \mathrm{~cm}$ gave no increased forage yields. Combining phosphorus with nitrogen resulted in yields no different from that due to nitrogen alone at the same level. Completion of soil tests subsequent to application of fertilizers in 1972 revealed 45 parts per million of phosphorus in the surface $2.5 \mathrm{~cm}$, 11 ppm between $2.6-25.4 \mathrm{~cm}$, and 21 ppm between 25.5-30.5 cm. Below this level down to $193 \mathrm{~cm}$ the phosphorus content varied between 1 and 3 ppm. Apparently there is sufficient phosphorus in the upper layers of these soils to supply the needs of the plants studied.

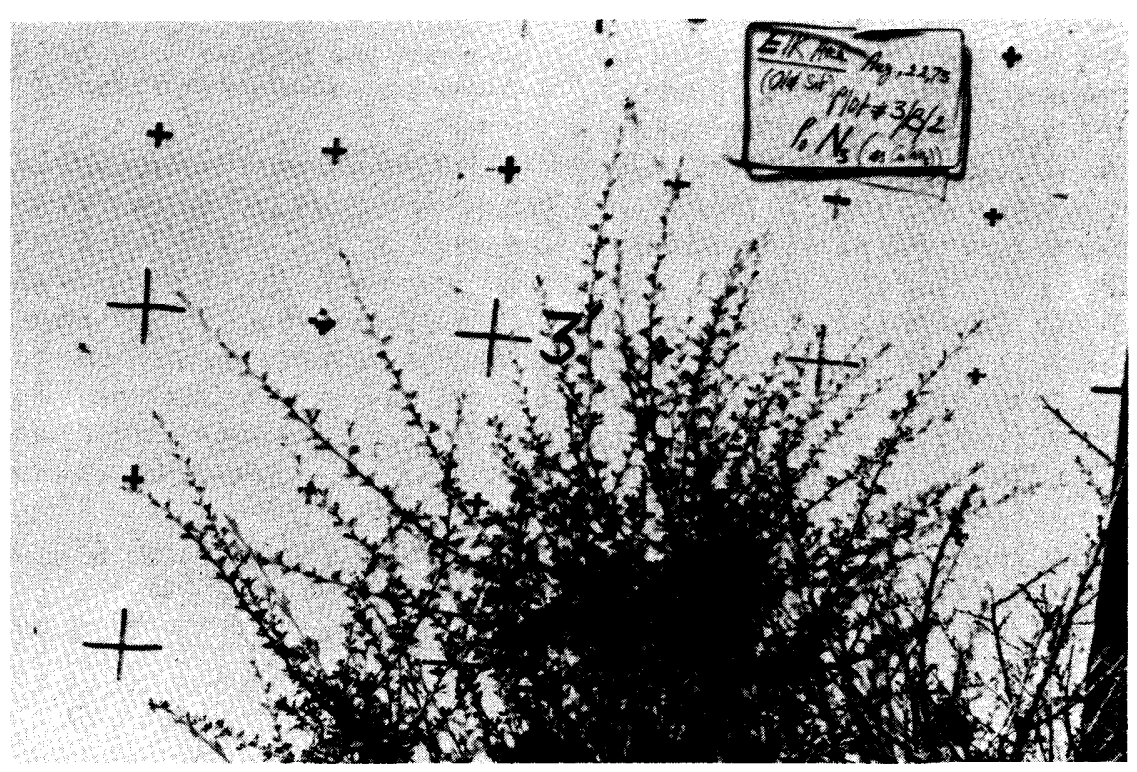

Fig. 1. Twig growth in 1973 of a bitterbrush plant fertilized in 1972 with $100.8 \mathrm{~kg}$ of nitrogen per hectare as $\mathrm{CaNo}_{3}$. The distances between large crosses is 1 foot; that between small crosses, 6 inches. 
Table 2. Increased production ( $\mathrm{kg} / \mathrm{ha})$ available for consumption of bitterbrush and sagebrush in 1972 and 1973 treatments.

\begin{tabular}{|c|c|c|c|c|c|c|}
\hline \multirow[b]{3}{*}{ Species } & \multicolumn{6}{|c|}{ Ycar and rate of application $(\mathrm{kg} \mathrm{N} / \mathrm{ha})$} \\
\hline & \multicolumn{2}{|c|}{1972} & \multicolumn{2}{|c|}{$1973^{1}$} & \multicolumn{2}{|c|}{1973} \\
\hline & 33.6 & $100.8^{2}$ & 33.6 & $100.8^{2}$ & 100.8 & $168.0^{3}$ \\
\hline Bitterbrush & 28.7 & 78.7 & 10.9 & 25.0 & 20.6 & 26.4 \\
\hline Sagebrush & 73.4 & 219.7 & 53.1 & 205.8 & 146.1 & 250.1 \\
\hline
\end{tabular}

${ }^{1}$ For 1972 treatments.

${ }^{2}$ Average increased production of $\mathrm{N}_{3}$ as ammonium nitrate, as calcium nitrate, and $\mathrm{N}_{3}$ as ammonium nitrate combined with $\mathrm{P}_{2}$.

${ }^{3}$ Average increased production of $\mathrm{N}_{5}$ as ammonium nitrate and as calcium nitrate.

may have been a factor with bitterbrush, but we have no explanation for the small carry-over response by sagebrush.

The use of twig lengths to measure browse production, adopted in the belief it would be more sensitive than other production indices, provided no quantitative data per unit area (Fig. 1). Accordingly, the average annual production of bitterbrush and sagebrush at Hardware Ranch in the summers of 1972 and 1973 were ascertained from unpublished reports by Jensen and Smith (1972 and 1973). These data were multiplied by the percentage increase in twig lengths for the respective species and year to estimate the additional forage attributable to fertilization (Table 2). These estimates represent the increased amounts of forage of these two browse species available for consumption by big game. Based on a daily forage intake by elk of 5.45 $\mathrm{kg} /$ day (U.S. Forest Service, 1958), the additional elk days of use due to nitrogen fertilization varied from 4 to 46 during the first year of application. Fertilization affected production of sagebrush more than bitterbrush.

Nitrogen fertilization increased the potential for production of bitterbrush and sagebrush in 1972 as indicated by the number of seeds and seed stalks, respectively (Table 3 ). Modest increases were observed in 1973 both in the 1972- and 1973-treated plots, though these were not significant at the 5\% level. In both years the maximum seed and seed-stalk production was observed at rates of $100.8 \mathrm{~kg}$ $\mathrm{N} /$ ha. The rates of nitrogen applied in
1973 , in excess of $100.8 \mathrm{~kg} / \mathrm{ha}$, actually depressed production. Production of seeds and seed stalks was not affected by phosphorus.

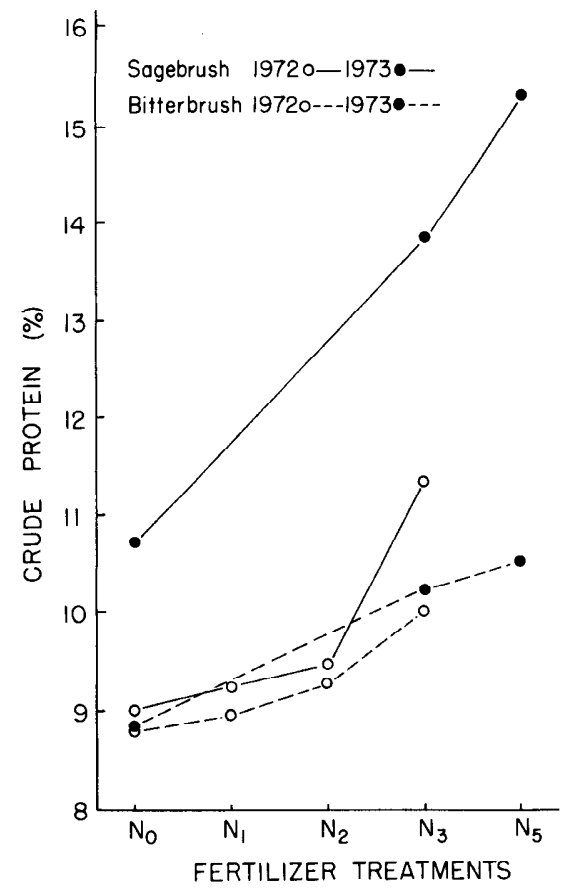

Fig. 2. Crude protein contents of leaves (1972) and leaves and twigs (1973) of bitterbrush and sagebrush in the fall as affected by fertilization with nitrogen.

Fertilization with nitrogen increased the crude protein content of the leaves in 1972 and of leaves and twigs combined in 1973 of both browse species (Fig. 2). Maximum percentage increases ranged between 1.23 and 1.68 for bitterbrush and 2.36 and 4.6 for sagebrush, resulting in increased protein yields of from 14 to
43\%. Sagebrush was affected more than bitterbrush in both years, and protein values were greater in 1973 than in 1972. The difference in percent of crude protein between 100.8 $\mathrm{kg} \mathrm{N} / \mathrm{ha}$ and $168 \mathrm{~kg} \mathrm{~N} / \mathrm{ha}$ was not significant. Other differences found in 1973 were highly significant; no statistical tests were possible in the 1972 leaf samples.

Greater use was made by game animals of the nitrogen-fertilized bitterbrush and sagebrush plants both in the winter of 1972-73 and 1973-74 (Fig. 3). However, the differ-

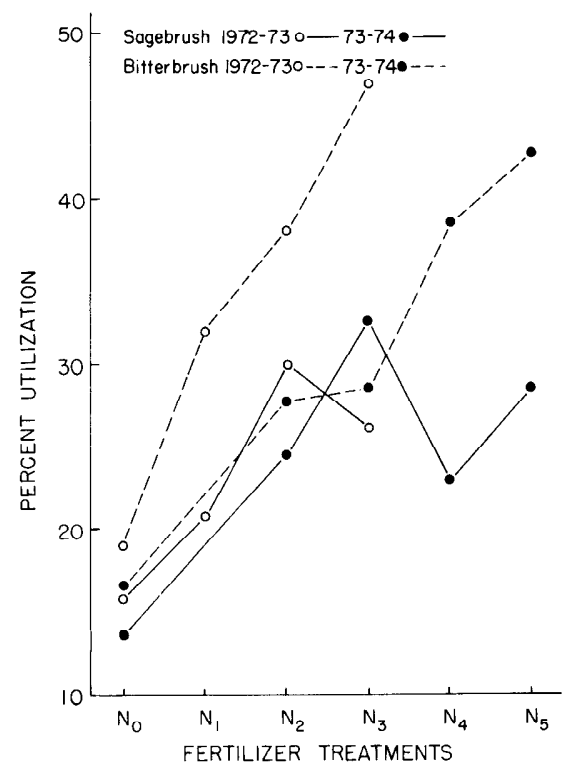

Fig. 3. The effect of fertilization with nitrogen on percentage utilization of bitterbrush and sagebrush by deer and elk during two winters.

ences were significant at the $1 \%$ level only in the case of bitterbrush in 1972-73. Once winter had set in, elk did not frequent the plots until emerging green vegetation provided more palatable forage than did shrubs. Deer, though present, were not abundant close to the ranch, presumably because of dominance by elk. Although in consequence, utilization by big game was lighter than was ex-

Table 3. Percent increase in production of seeds of bitterbrush and seed stalks of sagebrush per 0.099 square meter of cover on the 1972-treated plots in 1972 and 1973 and on the 1973-treated plots in 1973. ${ }^{1}$

\begin{tabular}{|c|c|c|c|c|c|c|c|c|c|c|}
\hline \multirow[b]{3}{*}{ Species } & \multicolumn{6}{|c|}{ 1972-treatments (kg N/ha) } & & & & \\
\hline & \multicolumn{2}{|c|}{33.6} & \multicolumn{2}{|c|}{67.2} & \multicolumn{2}{|c|}{100.8} & \multicolumn{4}{|c|}{ 1973-treatments $(\mathrm{kg} \mathrm{N} / \mathrm{ha})$} \\
\hline & 1972 & 1973 & $\overrightarrow{1972}$ & 1973 & 1972 & 1973 & $\overline{67.2}$ & 100.8 & 134.4 & 168.0 \\
\hline Bitterbrush & 32 & 13 & 17 & 23 & 78 & 31 & 4 & 37 & -9 & -17 \\
\hline Sagebrush & 92 & 17 & 200 & 34 & 233 & 63 & 2 & 24 & -5 & -22 \\
\hline
\end{tabular}

${ }^{1}$ The 1972 differences were significant at the $1 \%$ level; in 1973 differences were not significant at the $5 \%$ level. 
pected, the indication is strong that game animals preferred the fertilized shrubs.

\section{Discussion}

This study demonstrated that forage production and quality of bitterbrush and sagebrush can be increased by fertilization, although the practicability of this practice is nowise established. To evaluate the economics of applying nitrogen fertilizer to browse plants used as forage by big game, we arbitrarily selected two levels of nitrogen application for each year, $\mathrm{N}_{1}$ and $N_{3}$ for 1972 and $N_{3}$ and $N_{5}$ for 1973.

Two assumptions are possible regarding increased production: (1) that all of it is available for use since it represents an additional increment over that otherwise available for utilization and for protection requirements of the plant, or (2) that this, like other yields, should be reduced by an appropriate percentage (proper use) to maintain productivity of plants. The first assumes that the residual material required to maintain productivity of shrubs is a function of the amount of unbrowsed current growth remaining. If unfertilized plants produce more than enough twig growth to insure continued production, any increased growth resulting from fertilization could be eaten entirely without detriment. The second assumes that protection requirements are a percentage function of twig growth. The former is probably more nearly correct on normally productive ranges, where restoring the vigor of plants is unnecessary, and this assumption was followed.

We were able to document carryover responses of only 1 year from the 1972 treatment, and these are somewhat questionable. The winter of 1972-73 was especially severe, and bitterbrush suffered extremely heavy damage, presumably due to frost. Some plants were killed outright and crown kills were as high as $80 \%$ on others. Cook (1965) suggested that the increases to be expected from fertilization would be distributed 60,30 , and $10 \%$ in the first to third years after fertilizer application for seeded ranges in the Intermountain area. Since some of our rates of application were greater than his, we assumed carry-over effects for longer than 3 years. Although we know of no experience that would support our assumptions in this area,

Table 4. Increased elk days per hectare per treatment of bitterbrush and sagebrush for 1972 and 1973 treatments.

\begin{tabular}{ccrrrrrrr}
\hline \hline \multirow{2}{*}{$\begin{array}{c}\text { Year of treatment } \\
\text { and species }\end{array}$} & $\begin{array}{c}\text { Treatment } \\
\text { (kg N/ha) }\end{array}$ & 1972 & 1973 & 1974 & 1975 & 1976 & 1977 & Total \\
\hline 1972 treatment & & & & & & & & \\
Bitterbrush & 33.6 & 5.3 & 2.0 & 0.8 & & & & 8.1 \\
& 100.8 & 14.4 & 4.6 & 3.6 & 1.2 & & & 23.8 \\
Sagebrush & 33.6 & 13.5 & 9.7 & 2.6 & & & & 25.8 \\
& 100.8 & 40.3 & 37.8 & 14.6 & 4.9 & & & 97.6 \\
1973 treatment & & & & & & & & \\
Bitterbrush & 100.8 & & 3.8 & 2.3 & 1.1 & 0.4 & & 7.6 \\
& 168.0 & & 4.8 & 2.8 & 1.6 & 1.1 & 0.5 & 10.8 \\
Sagebrush & 100.8 & & 26.8 & 16.1 & 8.0 & 2.7 & & 53.6 \\
& 168.0 & & 45.9 & 25.5 & 15.3 & 10.2 & 5.1 & 102.0 \\
\hline
\end{tabular}

Power and Alessi (1971) report 6-year carry-over responses following fertilization of grasses in the northern plains. Carry-over effects were assumed to last for 3 years $(60,30$, and $10)$ at $\mathrm{N}_{1}, 4$ years $(50,30,15$, and 5$)$ at $\mathrm{N}_{3}$, and 5 years $(45,25,15,10$, and 5) for $\mathrm{N}_{5}$. The first year responses were equated to the assigned percentage and increased production for successive years were calculated. Because of erratic precipitation from year to year, actual results would not duplicate these assumptions. The additional elk days of forage provided by fertilization based on the above assumptions are shown in Table 4.

Costs were computed based on 1974 prices of ammonium nitrate ( $\$ 172$ per ton) and charges made by pilots for scattering the fertilizer with a light plane (\$35 per ton). The additional elk days of use provided by bitterbrush and sagebrush were combined. Depending upon the year and the rate of application, the cost per elk day in 1972 was $\$ .67$ at $33.6 \mathrm{~kg} \mathrm{~N} / \mathrm{ha}$ and $\$ .56$ at $100.8 \mathrm{~kg} \mathrm{~N} / \mathrm{ha}$. Because of lower yields in 1973, costs were even greater; $\$ 1.11$ at $100.8 \mathrm{~kg} \mathrm{~N} / \mathrm{ha}$ and $\$ 1.00$ at $168 \mathrm{~kg} \mathrm{~N} / \mathrm{ha}$. These calculations are conservative; it is improbable, given the unpredictability of game animals, that all of the increased production would be harvested. To the extent that forage remained unharvested, actual costs per elk day would be increased. Moreover, most of the additional forage was provided by sagebrush. Because of variability in palatability of this species from plant to plant, it is not to be expected that all the increased yield would be harvested. Some sagebrush plants remain unused even under moderately heavy winter use by big game. Assuming only half of the sagebrush plants were palatable, the cost per additional elk day would be: $\$ 1.54$ at $33.4 \mathrm{~kg} \mathrm{~N} / \mathrm{ha}$, $\$ .94$ in 1972 and $\$ 1.97$ in 1973 at $100.8 \mathrm{~kg} \mathrm{~N} / \mathrm{ha}$, and $\$ 1.10$ at $168 \mathrm{~kg}$ $\mathrm{N} / \mathrm{ha}$. Obviously, these costs are higher than can be justified under present game management conditions.

Admittedly, in a multiple use situation with domestic livestock using the range during the growing scason, the increased production of herbaceous species can defray part of the cost. Because we documented the response of only three herbaceous plants, we are unable to evaluate realistically the benefits to livestock. The results obtained show potentials for improvement in production of big game forage if fertilization can be justified by the increased livestock forage produced. This seems unlikely in view of the economic analysis of fertilization made by Workman and Quigley (1974). They found fertilization on range sites similar to ours was not economically profitable; moreover, prices for fertilizer are now more than twice as high as when their analysis was made.

Although there was some preference exhibited by elk, or deer, for the fertilized shrubs, it was not so marked as to indicate fertilization could be used as a means of controlling movements and distribution of big game animals as Brown and Mandery (1962) suggested and the observations of Geist et al. (1974) imply.

\section{Literature Cited}

Anderson, B. L. 1972. Growth response and deer utilization of fertilized browse. MS Thesis, New Mexico State University.

Brown, E. R., and J. H. Mandery. 1962. Planting and fertilization as a possible means of controlling distribution of big game animals. J. Forest. 60:33-35.

Carpenter, L. H. 1971. Middle Park deer study-range fertilization. Colo. Div. Game, Fish and Parks Project 
W-38-R-25. Game Res. Rep. Part 3. p. 225-253.

Cook, C. W. 1961. Mountain range can produce more forage. Colorado Rancher and Farmer 15:18.

Cook, C. W. 1965. Plant and livestock responses to fertilized rangelands. Agr. Exp. Sta. Bull. 455, Utah State Univ., Logan. 35 p.

Cook, C. W., and L. A. Stoddart. 1959. Nitrogen fertilizer on range areas shows excellent Benmore results. Range Improvement Notes 4(3):4-5.

Geist, J. M., P. J. Edgerton, and G. S. Strickler. 1974. 'Yukky to Yummy'with Fertilizers. Rangeman's J. 1:39-41.

Harris, L. E. 1970. Nutritional research techniques for domestic and wild animals, Vol. 1; An international record system and procedures for analyzing samples, 2501-5. Lorin E. Harris, Publ., Logan, Utah.
Jensen, C. H., and A. D. Smith. 1972 and 1973. The effects of livestock grazing in spring on big game winter range. Job Progress Reports. Utah Federal Aid Project W-105-R, Job A4P. (Multilith).

Pechanec, J. F., and G. D. Pickford. 1937. A weight estimate method for the determination of range or pasture production. $J$. Amer. Soc. Agron. 29:894-904.

Power, J. F., and J. Alessi. 1971. Nitrogen fertilization of semiarid grasslands: Plant growth and soil mineral $\mathrm{N}$ levels. Agron. J. 63:277-280.

Smith, A. D., and D. D. Doell. 1968. Guides to allocating forage between cattle and big game on big-game winter range. Utah State Division of Fish and Game Pub. 68-11. $32 \mathrm{p}$.

Smith, A. D., and P. J. Urness. 1962. Analyses of the twig-length method of determining utilization of browse. Utah
State Dep. Fish and Game Pub. 62-9. $35 \mathrm{p}$.

Smith, G. E. 1963. Nutritional effects of big sagebrush (Artemisia tridentata) on deer. MS Thesis, Oregon State Univ., Corvallis. $111 \mathrm{p}$.

U.S. Forest Service. 1958. Wild life management. Forest Serv., U.S. Dep. Agr. Forest Service Handbook, Chapter 2620. $117 \mathrm{p}$.

Williams, G. L. 1972. Sagebrush and mulies. Colorado Outdoors 21(2):11-13.

Wood, G. W., and J. S. Lindzey. 1967. The effects of forest fertilization on the crude protein, calcium, and phosphorus content of deer browse in a mixed oak forest. The Pennsylvania Cooperative Wildl. Res. Unit Pap. 126. (mimeo.)

Workman, J. P., and T. M. Quigley. 1974. Economics of fertilizer application on range and meadow sites in Utah. J. Range Manage. 27:390-393. 